\title{
Corruption and Political Participation: A Review
}

\author{
Milan Školník'
}

\begin{abstract}
A number of studies have explored how corruption affects political participation, specifically whether it discourages or mobilizes it. Although research on this topic has been on the rise in recent years, it is in the vast majority of cases limited to the quantitative data gathered by Transparency International on the one hand (in particular the Corruption Perceptions Index) and to statistics concerning voter turnout on the other hand. This review article not only summarizes the results to date in this area but also takes into account different kinds of research. It includes aggregate and individual-level data, as well as experiments. Another contribution of this paper is that it explores forms of political participation not limited to voter turnout and also monitors the impact of corruption on participation in, for example, demonstrations and political meetings. The article also differentiates between perceptions of corruption, experience with corruption, and the impact of corruption scandals on political participation. The results reveal that corruption generally discourages political participation. However, there are also a number of studies indicating that, on the contrary, it can lead to political mobilization.
\end{abstract}

KEYWORDS corruption, demonstrations, meetings, participation, turnout, voter behaviour

\section{Introduction}

In recent years, research into the relationship between corruption and political participation has become more common. While most political science and sociological debates about corruption and its influence on society suggest that it is a negative social phenomenon with negative societal impacts ${ }^{2}$, there is no such consensus when it comes to its impact on political participation.

\section{Sociálni studia / Social Studies 1/2020. Pp. 89-105. ISSN 1214-813X.}

1 The author has received funding from the Philosophical Faculty of the University of Hradec Králové (Specific research grant "Comparative analysis of Latin American politics").

2 There are several major debates in the existing literature on how corruption affects society (Jain 2001). Authors specifically focus on whether it affects interpersonal or institutional trust (Ares and Hernández 2017; Naxera 2012; Obydenkova and Arpino 2018; Richey 2010; SoléOllé and Sorribas-Navarro 2018; Weng et al. 2015). There is also a debate on the relationship between corruption and the economy, specifically on whether corruption distorts the functioning of the market, undermining the economy and thus slowing development (Blackburn et al. 2006, 2010; Haque and Kneller 2005; Kunieda et al. 2016; Tsaturyan and Bryson 2010). Studies have also sought to determine which electoral systems lead to a reduction of corruption and which electoral rules present, on the contrary, a breeding ground for corruption (Buben and Kouba 2017; Chang and Golden 2007; Myerson 1993; Persson et al. 2003). 
The aim of this review article is to offer an evaluation of the existing research in this area and present the forms of corruption and political participation that are currently being studied, as well as the trends and conclusions of previous research. Attention is also paid to the data through which corruption and political participation are operationalized. The current article also expands the most recent review article dealing with the electoral consequences of corruption (De Vries and Solaz 2017). ${ }^{3}$

Corruption can be defined as "behavior which deviates from the formal duties of a public role because of private-regarding (personal, close family, private clique) pecuniary or status gains; or violates rules against the exercise of certain types of private-regarding influence" (Nye 1967: 419). The world's largest organization dealing with corruption, Transparency International, uses a shorter definition of corruption: "abuse of entrusted power for private gain" (Transparency International 2019). Although these two definitions are the most commonly used, there are many others, and there is no consensus in the literature. However, they are similar in nature and are characterized by abuse of power for private purposes.

The problem of definitions of corruption is their universality. Defining corruption is also related to its conceptualization. Each researcher either follows a general definition or adapts it for his purposes. The biggest problem in defining corruption seems to be that most research on corruption is based on subjective impressions. Interviewers and authors assume that respondents, whether experts or citizens, know what corruption means (a misuse of power for private purposes). The counter-argument is, because corruption is first and foremost a sociological phenomenon, there may be significant cultural differences between societies in how they understand corruption (Kurer 2015: 36). Only a few studies have tried to address this. They conclude that a general awareness of what corruption is and what is unacceptable (such as outright bribery to speed up a procedure, influencing tax officials to reduce taxes, bribery in government contracts, nepotism in public service) exists for most respondents (Beck and Lee 2002; Truex 2011). However, other research demonstrates that there may be differences. In particular, what was considered a corrupt activity in China was not considered corrupt in the West (Sun 2001). ${ }^{4}$

\section{The Relationship Between Corruption and Political Participation}

The theoretical argument is that corruption undermines inclusivity in political processes, tarnishing the relationship between citizens and their elected representatives (Warren 2004).

The current article not only expands on De Vries and Solaz's (2017) latest article, but also deals with the relationship between corruption and political participation in general (i.e. it addresses forms of political participation other than voting).

4 Even though this review article draws attention to the issue of defining corruption and offers explanations as to why the results may vary depending on the data researchers work with, it is focused primarily on how corruption affects political participation. More narrowly, it focuses on what prevails in the ongoing debate on this topic, at both the national and local levels. The topic of different perceptions of corruption still deserves attention, as it may be the cause of the different impacts corruption has in different cultures. 
Basically, corruption weakens the voice of citizens by transferring power and resources from the public to the private sphere, in which individualism and a desire for profit thrive. As a result, democratic legitimacy is weakened as citizens are excluded from political decision-making. Moreover, as corruption spreads, citizens gradually lose confidence in the political process that they no longer perceive as publicly accessible, and, as a result, they become more and more cynical and withdraw from participating in such an exclusive environment. The horizon of collective action within the political system is thus significantly reduced as a result of corruption (Warren 2015). An example of this can be seen in the electoral process. Within a democratic system, elections represent an important decision-making procedure in which citizens select the ruling elite and essentially participate in the administration of their country (Dalton and Klingemann 2007). The general premise is that high turnout requires elected officials who are credible and act in accordance with the desires of their constituency (Putnam 1993). If citizens perceive political leaders as corrupt, they often prefer not to vote, because they believe that their voices cannot change the corrupt environment. They therefore remove themselves from the political process. In this way, the political discontent associated with corruption can result in political apathy through a process of indignation (Anderson and Tverdova 2003; Bauhr and Grimes 2014). Corruption thus represents a deterrent to voter turnout (Ecker et al. 2016; De Vries and Solaz 2017).

Conversely, a number of studies suggest a very different theoretical argument: corruption can provoke political mobilization, which can act in two ways. Firstly, elections represent a unique opportunity for voters to punish the politicians involved in corruption by supporting alternative candidates. In this way, the citizen is targeted in the political process. This type of mobilization represents a possible effect of corruption that contrasts with the political apathy previously described (Welch and Hibbing 2006; Xezonakis et al. 2016). Furthermore, voters can also choose to intentionally vote for corrupt candidates. This is often the case in systems with a high degree of electoral clientelism in which politicians exchange votes for public goods. Certain voters benefit from this exchange, which leads them to have greater confidence in these politicians and re-elect them, allowing their corrupt practices to continue (Manzetti and Wilson 2007). These contrasting theoretical arguments are a source of constant academic debate.

A limitation of much prior research is that it focuses primarily on voter turnout, neglecting other forms of political participation. Just because citizens choose not to vote due to corruption does not necessarily mean that they are not engaging in other forms of political participation, such as protest rallies, which allow them to express their opinions in another way. There are, in fact, many different types of political participation, from voting to more radical forms such as demonstrations. In the scholarly literature, they are most often divided into the categories of institutionalized and non-institutionalized. The difference is that the forms of political participation in the first group are usually regulated by the political elite, while those in the latter are organized by citizens (Kaase 1999). The institutionalized framework includes, for example, elections, participation in political party meetings, political party membership, and the practice of contacting politicians. The non-institutionalized forms of political participation are characterized by acts such as signing petitions, boycotting certain products and services for political reasons, and participating in protest rallies. Their purpose is to challenge the political elite or to gain access to the political agenda (Hooghe 
and Marien 2013: 138-139; Inglehart 1997). Elections are undoubtedly the most widespread form of political participation, so it is not surprising that they are the most frequently represented in academic research examining the relationship between corruption and political participation. However, unlike the other forms, the frequency of participation in elections is limited: one vote per person per election. Focusing on voter turnout thus provides an incomplete picture of the true level of political participation.

\section{Measuring Corruption and Political Participation}

In the early debates on the impact of corruption, researchers struggled to find ways to measure this phenomenon that is difficult to detect, illegal and, by its nature, based on the human desire for profit, albeit at the expense of society. Over time, however, several approaches to measuring corruption have been developed.

Corruption variables are divided mainly into perceptions of corruption (either public or experts), experiences with corruption (or participation in corruption), and corruption scandals. While the first two variables are generally based on global and regional opinion polls and data gathered by specialized organizations such as Transparency International, the element of scandals remains difficult to evaluate.

\section{Perception}

The perception of corruption measures the degree of corruption that an individual believes exists. The Corruption Perceptions Index, ranging from the lowest level of corruption to the highest on a scale from 0 to 100 , is compiled by the largest organization dealing with corruption issues, Transparency International. It is one of the most common and well-known indicators used to assess the phenomenon of corruption. This index is made up of aggregated data that reflects the perception of corruption among businessmen and experts. The Control of Corruption Index managed by the World Bank is composed of expert surveys. However, some of its subcomponents include Gallup surveys of non-experts, which contrasts with the Corruption Perceptions Index (Roca 2010). The World Bank, in collaboration with other organizations, also conducts the Business Environment and Enterprise Performance Surveys. These are elite surveys, as more than 150,000 companies operating in different countries are surveyed. Representatives of companies are mainly asked whether a bribe was expected or explicitly required when arranging a business contract or license with the government (The Enterprise Surveys 2019). There is also the International Country Risk Guide compiled by the PRS Group, an aggregate that includes the degree of corruption in the country. V-Democracies works with more than 3,000 experts. Although V-Democracies focuses on the conceptualization and measurement of democracy, its components include the Political Corruption Index, Executive Corruption Index, and Public Sector Corruption Index. The Electoral Integrity Project assesses the quality of elections in different countries based on expert surveys. The databases of this project, which is conducted under the leadership of Pippa Norris, contain questions about electoral fraud (The Electoral Integrity Project 2019). Electoral fraud can be considered a form of corruption (Dočekalová 2012). 
An alternative to the CPI is the Global Corruption Barometer from the same organization. It does not include expert surveys, but household surveys. Individual data based on citizens' opinions on corruption and political participation are provided by a number of other organizations specializing in conducting polls. These include the International Social Survey Program (ISSP) and the Comparative Study of Electoral Systems (CSES), which both conduct thematic surveys at regular intervals. Furthermore, there are several organizations providing more specific regional surveys: in Latin America, there are the AmericasBarometer and the Latinobarómetro; in Africa, data are gathered by the Afrobarometer; and in Europe, there is the Eurobarometer. Samples and questions vary depending on the organization that collects the data. Interviewers generally ask questions such as "Thinking of the politicians in your country how many of them do you believe are involved in corruption?" or "How much corruption do you think there is in National Government" (Latin American Public Opinion Project 2019; Latinobarómetro 2019). Furthermore, these polls include not only general questions but also very direct questions about the specific actors involved in the institutional organization of the state. The surveys often enquire about the perceived level of involvement in the corruption of judges, state officials, the police, and the military.

\section{Experience}

Experience with corruption is generally evaluated through questions about the most common form of corruption - bribery (Amundsen 2019). Questions about individuals' experience with corruption are not straightforward in terms of whether the interviewee has experience with corruption, in this case with bribery. This experience can take a number of different forms. Respondents can, for example, merely be aware of the fact that a civil servant (a clerk, a police officer, or even a soldier) has demanded a bribe; they can also play a more active role by having paid a bribe themselves or been a direct witness to a bribe payment (Morris 2008). In the current research, however, these different experiences are uniformly classed as experience of or participation in corruption, regardless of the specific situation. Public opinion databases such as ISSP, AmericasBarometer and others include specific questions on the experience of corruption.

\section{Scandals}

The data on corruption scandals is most often based on reports from investigating authorities (e.g. Parliament's Ethics Committee, Supervisory Authority etc.) and media (e.g. the Latin American Weekly Report on the progress of corruption scandals) that report on corruption among politicians, especially when they are seeking re-election (Balán 2011; Karahan et al. 2006; Cámara-Fuertes and Bobonis 2015; Praino et al. 2013). Targeted questions on corruption scandals can also be found in specialized polls (e.g. the American National Elections Study). Furthermore, there is useful information in local databases dealing with corruption scandals that compile data from media reports, such as those managed by Spanish and Italian local administrations (Costas-Pérez et al. 2012; Fernández-Vázquez, Barberá and Rivero 2016; Giommoni 2017). Combining these databases with the results of polls, 
as demonstrated in follow-up research at the level of Spanish municipalities, can also yield interesting results (Riera et al. 2013). Panel surveys conducted before and after the outbreak of scandals represent another valuable source (Vivyan et al. 2012).

\section{Experiments}

Finally, there are a number of experiments testing the impact of corruption awareness on voter turnout and election protests. In one, a leaflet is distributed to a constituency informing the citizens about their candidate's corruption before the elections, while no such information is delivered to a second constituency. This test is designed to evaluate how voter awareness of corruption affects election results (Chong et al. 2015; De Figueiredo et al. 2011). In other studies, participants are divided into two groups, with one group being provided with information about corruption, while the other is not; both groups are then asked questions about their interest in political participation (Inman and Andrews 2015; Muñoz et al. 2016).

\section{Problems of Conceptualization of Corruption}

Distinguishing between the aggregated and individual data about the perception of corruption is essential but often neglected. Some studies have shown that the degree of corruption perceived by the experts and businessmen interviewed by Transparency International may differ significantly from the views of citizens (Roca 2010; Treisman 2007; Weber Abramo 2008). There may be several reasons why aggregate and individual data differ across countries and hence the final research results as well. The views of international experts may differ due to personal ideology, cultural bias, or the echo-chamber problem. With respect to citizens, their restraint or fear of giving true answers on sensitive topics may be a problem. Furthermore, the data may reflect a high threshold for corruption tolerance, especially in countries where corruption is a common phenomenon (Lin and Yu 2014: 153). Research on corruption at the local level using individual-level data may yield different results due to different ways of operationalizing corruption. Examining the impact of corruption on political participation in Latin America, Neshkova and Kalesnikaite (2019) suggest that the experience of corruption is a much stronger predictor of involvement in local government activities, such as participation in city councils, than the perception of corruption. This is because petty corruption is more prevalent at the local level and respondents are more likely to have encountered it.

\section{The Deterrent Effect of Corruption}

Several existing empirical studies find a correlation between corruption and voter turnout. Both Hellman et al. (2000) and Tucker (2007) argue that the widespread perception of government corruption leads to fewer citizens making the journey to the polling stations. Stockemer (2013) uses three indicators to measure corruption, namely the International Country Risk Guide and the data compiled by Transparency International and the World 
Bank. Across a large sample of presidential regimes, he finds that only the International Country Risk Guide, in particular its corruption component, reveals a negative impact on voter turnout. The other two indicators of corruption do not appear on the macro-level. An analysis of data between 1984 and 2009 based on a sample of 72 electoral democracies finds that countries with greater corruption control also have higher voter turnout. Conversely, as corruption rises in the eyes of citizens, the percentage of voters participating in elections decreases. In this study, corruption is measured using the International Country Risk Guide Index (Stockemer et al. 2013). After examining corruption and voter turnout across 172 regions in Europe, Sundström and Stockemer (2015) reaffirm the argument that political corruption leads to low voter turnout in regional elections. Simpser (2004) also discusses the negative impact of electoral corruption. His extensive N-study research, covering mainly the 1990s, focuses on both autocracies and democracies.

Using individual-level research, McCann and Dominguez (1998) and Birch (2010) likewise demonstrate that the perception of electoral fraud negatively affects voter turnout. The first study is based on a national opinion poll conducted in Mexico and indicates that respondents who believe that corruption is widespread are much less likely to vote than those who believe that their elected representatives are clean. The second study uses CSES data to determine that voters who perceive elections as fair are more likely to participate in them than those who perceive them as manipulated. This research focused on both new and established democracies. It is not only corruption that reduces voter turnout but also the inability and inefficiency of the government.

Two Brazilian surveys demonstrate that awareness of corruption has a negative impact on voter turnout, despite the fact that Brazil has enforceable compulsory voting (Ferraz and Finan 2008; De Figueiredo et al. 2011). Another study in the US state of Louisiana using data collected through telephone surveys confirms the finding that voter turnout decreases when the perception of corruption is high (Caillier 2010). Tatiana Kostadinova (2003, 2009) reports mixed results using CSES data for eight post-communist countries in Eastern Europe. Although she finds a weak positive effect of political corruption on voter turnout, it is counterbalanced by the negative effect of corruption perception on political efficiency, which in turn reduces voter turnout. In the long term, Kostadinova's results indicate that the deterrent effect of corruption prevails, as its mobilizing effect proves to be much weaker. Another experimental study based in Mexico explores the relationship between corruption, specifically awareness of corruption, and voter turnout in 12 municipalities. It concludes that corruption indeed reduces voter turnout in these constituencies (Chong et al. 2015). Similarly, research by Spanish municipalities refutes the mobilization impact of corruption at the local level, finding that politically unreached voters tend to withdraw from the electoral process rather than mobilize against corruption (Costas-Perez 2014). The same conclusions are reached in a study of Italian municipalities (Giommoni 2017).

Research combining individual CSES data with National Quality of Government data from a sample of 26 countries reveals that corruption reduces voter turnout in systems with low to medium levels of corruption. In countries where corruption has truly permeated the political system, it has no effect on voter turnout (Dahlberg and Solevid 2016). The most recent study concerning Colombia proves that voters with credible information 
about a candidate's corruption are less likely to participate in elections than those that are uninformed. Furthermore, this article rebuts the theory of clientelistic ties leading voters to willingly support corrupt politicians in exchange for personal gain. Carreras and Vera (2018) also emphasize that "electoral participation is just one of the many ways citizens can participate in politics. It is entirely possible for citizens to resist corruption by engaging in non-institutionalized political actions such as joining anti-corruption demonstrations" (Carreras and Vera 2018: 13). Elections are indeed not the only decisive mechanism for combating political corruption from a citizen's perspective (Xezonakis et al. 2016). The most recent research on Spanish municipalities tested how corruption cases manifested themselves in relation to voter turnout between 1999 and 2011. The authors found that corruption at the local level reduces turnout, and that right-wing voters are more loyal to their parties and more tolerant of corruption (Jiménez and García 2018).

\section{Mobilization Effect of Corruption}

Research into US local and gubernatorial elections, however, suggests that corruption has a mobilizing effect, encouraging citizens to vote (Escaleras et al. 2012; Karahan et al. 2006). Using data from 1979 to 2005 on the number of public officials convicted of corruptionrelated crimes compared with voter turnout, Escaleras et al. (2012) demonstrate that voter turnout is higher in states with more allegations of corruption. Stockemer and Calca (2013) argue that while high corruption at the national level leads to lower turnout, the effect on the subnational level is often the opposite. This is revealed in their research into Portuguese districts. Also of note is a study examining the electoral behaviour in Senegal. Using an experimental research design and Afrobarometer data, Inman and Andrews (2015) find support for allegations that more widespread perception of government corruption leads to higher turnout. Controlling for party affiliation, they conclude that only non-partisans have a greater interest in politics in response to corruption. Corruption does not appear to affect members of Senegal's political parties in this way. A field study involving 298 Israeli participants indicates that the perception of corruption leads to political participation, but this relationship is influenced by the way in which citizens perceive corruption. The conclusions are that both the perception of corruption and the public's conception of corruption should be seen as important indicators of participation (Navot and Beeri 2017).

Little evidence supports the theory that one effect of corruption is that it mobilizes citizens to vote against corrupt politicians by instead voting for another candidate. Only a minute proportion of corrupt politicians are successfully punished in this way, which in the long term significantly weakens the mobilization effect of corruption (Costas-Pérez et al. 2012; Dimock and Jacobson 1995; Pattie and Johnston 2012).

A number of recent studies on corruption and political participation that use data at the aggregate, individual, and experimental levels demonstrate that corruption reduces voter turnout. However, there are also many studies that use the same types of data yet reach the conclusion that corruption increases turnout.

One way to explain this difference is by the size of the samples examined. Research at the aggregate and at the individual levels involving multiple countries tends to agree that 
corruption reduces voter turnout (Stockemer et al. 2013; Sundström and Stockemer 2015). The opposite conclusion is mainly reached in local research.

\section{No Correlation Between Corruption and Voter Turnout}

Several studies examine the relationship between corruption and political participation and conclude that there is no correlation between these variables; two such studies demonstrate this with US data (Peters and Welch 1980; Shaffer 1981). Both these studies argue that corruption and the likelihood of voter turnout are unrelated. Extensive research involving 115 developing countries adds that the perception of corruption is not one of the factors influencing election results, because the economy is generally more important to citizens (Choi and Woo 2010).

\section{Influence of Corruption on Institutionalized and Non-institutionalized Forms of Political Participation}

Regarding more radical and unconventional forms of political participation, several studies have highlighted that corruption can lead to increased participation in demonstrations against the abuse of power and the use of public money for private purposes. Research into this question has focused mainly on the Latin American region, where corruption is widespread (Gingerich 2009; Machado et al. 2011). Sofia A. Olsson (2014) is a scientific pioneer who has worked with both non-institutionalized and institutionalized forms of political participation. Although Olsson's conclusions confirm the negative impact of corruption on electoral turnout, her hypotheses about the relationship between corruption and institutionalized and non-institutionalized political participation have yet to be validated, and further research is therefore required in this field. Hooghe and Quintelier (2014) also divide political participation into the categories of institutionalized and non-institutionalized; they use European Social Survey data to monitor the impact of a number of variables, including corruption, on these forms of participation. They find that corruption has a negative impact on political participation, with the level of participation being lowest in countries with the highest levels of corruption.

For a broader picture of how corruption affects political participation, it is important to have a better understanding of corruption. The authors of a study focused on Latin American countries using the AmericasBarometer distinguish between the perception, experience, and tolerance of corruption (Bonifácio and Paulino 2015). These elements are evaluated at the individual level, based on respondents' answers to the survey. The authors examine the effects of three forms of corruption on five kinds of political participation: contact with political and governmental actors, community activism, partisan and electoral activism, voter turnout, and protest activism. Their findings reveal that both the experience of corruption and the tolerance of corruption increase the likelihood of political participation. The results concerning the perception of corruption are too variable to deduce any sort of trend. Their research is unique in its complexity and is one of the few studies that takes into account both various forms of corruption and different forms of political participation. The perception 
of corruption and experience with corruption is also discussed in another article on the Latin American region, which focuses on the local level and uses AmericasBarometer data. This database provides survey answers not only on various forms of corruption, but also on various forms of political participation, such as whether the respondent attended city council meetings in the last 12 months. The results of the analysis reveal that experience with bribery of public officials mobilizes local political participation, whereas the perception of corruption tends to discourage political participation (Neshkova and Kalesnikaite 2019). These conclusions are in line with similar research focusing on three South American countries, Chile and Venezuela (Školník 2019) and Colombia (Školník 2020), which also use the AmericasBarometer data.

One of the latest studies, which works with individual ISSP data in a sample of 34 countries, also addresses the impact of corruption on non-electoral forms of political participation. However, this research combines different forms of political participation, including taking part in a demonstration, signing a petition, participating in a boycott, attending a political meeting or rally, contacting a politician, contacting the media, and donating money or raising funds for a political cause in the past year, into one dependent variable. Corruption, according to this research, has a positive impact on non-electoral forms of political participation, but the effect is primarily among people with lower levels of education and less political interest who hold anti-elitist views and tend to engage in noninstitutionalized forms of political participation (Bazurli and Portos 2019).

The effects of corruption on multiple forms of political participation are also tested in an article that uses data from the Hungarian post-election survey from 2014. Corruption in this research takes three forms (experience with bribery, perceptions of widespread corruption, and concerns about increasing corruption). The perception of corruption has a deterrent effect on voter turnout. Concerns about the increase in corruption, by contrast, may lead to participation in both institutionalized and non-institutionalized forms. Experience with bribery leads to involvement in various forms of political participation, but it is not a reason for voting in elections (Kostadinova and Kmetty 2019).

\section{Conclusion}

Although corruption is an important topic in many fields, research into the relationship between corruption and political participation has only begun to grow in intensity in the last five to ten years, as demonstrated by the literature review. Most studies use the Transparency International Corruption Perceptions Index data as an independent variable and voter turnout as a dependent variable. However, there are also some articles that address corruption on an individual level or opt for experimental design, reflecting the diversity of this academic debate.

Research at the national level in the vast majority of cases seems to confirm the deterrent effect of corruption, while at the regional and local levels the results are rather more ambiguous, suggesting not only a deterrent but also a mobilizing effect of this phenomenon. To explain this discrepancy, it is important to highlight the different ways that these studies measure corruption. All transnational studies work with statistics 
on the perception of corruption, while regional studies are based on data about the number of politicians accused as a result of corrupt practices, namely the awareness of corruption (Escaleras et al. 2012; Stockemer and Calca 2013). Perceived corruption indicates how much respondents view corruption in their country as being widespread. With regard to the latter, it is often difficult to interpret the significance of the number of officials convicted as a result of corruption: whether a high number signals that the political system is very corrupt, or that it is effective at tackling corruption.

Table 1: Summary

\begin{tabular}{|c|c|}
\hline The Deterrent Effect of Corruption & Mobilization Effect of Corruption \\
\hline $\begin{array}{l}\text { McCann and Domínguez } 1998 \\
\text { Hellman, Jones and Kaufmann } 2000 \\
\text { Kostadinova 2003, } 2009 \\
\text { Simpser } 2004 \\
\text { Tucker } 2007 \\
\text { Ferraz and Finan } 2008 \\
\text { Birch } 2010 \\
\text { Caillier } 2010 \\
\text { De Figueiredo et al. } 2011 \\
\text { Stockemer } 2013 \\
\text { Stockemer, LaMontagne and Scruggs } 2013 \\
\text { Costas-Perez } 2014 \\
\text { Chong et al. } 2015 \\
\text { Sundström and Stockemer } 2015 \\
\text { Dahlberg and Solevid } 2016 \\
\text { Xezonakis et al. } 2016 \\
\text { Giommoni } 2017 \\
\text { Carreras and Vera } 2018 \\
\text { Jiménez and García } 2018\end{array}$ & $\begin{array}{l}\text { Dimock and Jacobson } 1995 \\
\text { Karahan et al. } 2006 \\
\text { Costas-Pérez et al. } 2012 \\
\text { Escaleras, Calcagno and Shughart } 2012 \\
\text { Pattie and Johnston } 2012 \\
\text { Stockemer and Calca } 2013 \\
\text { Stockemer et al. } 2013 \\
\text { Inman and Andrews } 2015 \\
\text { Sundström and Stockemer } 2015 \\
\text { Navot and Beeri } 2017\end{array}$ \\
\hline $\begin{array}{l}\text { No Correlation Between Corruption } \\
\text { and Voter Turnout }\end{array}$ & $\begin{array}{l}\text { Influence of Corruption on Institutionalized } \\
\text { and Non-institutionalized Forms of Political Participation }\end{array}$ \\
\hline $\begin{array}{l}\text { Peters and Welch } 1980 \\
\text { Shaffer } 1981 \\
\text { Choi and Woo } 2010\end{array}$ & $\begin{array}{l}\text { Gingerich } 2009 \\
\text { Machado, Scartascini and Tommasi } 2011 \\
\text { Hooghe and Quintelier } 2014 \\
\text { Olsson } 2014 \\
\text { Bonifácio and Paulino } 2015 \\
\text { Bazurli and Portos } 2019 \\
\text { Neshkova and Kalesnikaite } 2019 \\
\text { Kostadinova and Kmetty } 2019 \\
\text { Školník } 2019 \\
\text { Školník } 2020\end{array}$ \\
\hline
\end{tabular}

Given that the preponderance of existing research is limited to the most typical form of political participation, electoral participation, the scope of future research should be expanded to include other forms of political participation that could also be influenced by corruption. Study samples should be selected to compare not only individual countries but also international regions. Existing research has, after all, already demonstrated regional differences: in Latin America, some forms of corruption appear to lead to political participation, while in many European countries corruption in general is a significant disincentive. 
Attention needs to be paid to the different outcomes of corruption perception among experts and citizens. Future measurements should be comparable across space and time in order to discern trends rather than one-off studies producing different results. Aggregated data at the national level should be compared with individual data at the national level. Data such as that from the Corruption Perceptions Index should not be combined with the results of local surveys, which are usually narrowly focused on the selected country or location, which makes international comparison inappropriate. These comments relate to what was indicated in the introduction - there should be new research about what corruption means to respondents in different countries and cultures and where the tolerance threshold for corruption is. In general, what is needed is a better understanding of corruption.

Finally, further research should seek the best predictors for engaging in different forms of political participation. For instance, further research could investigate whether perceived corruption or experience with corruption are strong predictors, as some research suggests (Neshkova and Kalesnikaite 2019). This research should be conducted at both the national and local levels.

In conclusion, political participation and citizen involvement in general is healthy for any civil society. If corruption affects political participation, it is necessary to know how. Corruption may be a deterrent leading to the resignation of citizens and their indifference to the political system. On the contrary, it may also have a mobilizing effect, especially for unconventional types of political participation, such as demonstrations, which may lead to violence or social instability. This article has noted that, just as it is difficult to fight corruption, it is also difficult for social scientists to accurately assess this diverse phenomenon and test hypotheses about its effects. However, in order to fight corruption effectively, it is essential to know what impacts it can have on society. At the very least, the debate on corruption and political participation is well underway, as demonstrated by the growing number of studies in this area, and the growing diversity of research, as manifested by the inclusion of various forms of corruption and political participation. Nevertheless, there is still much work to be done.

\section{References}

Amundsen, Inge. 2019. "Extractive and Power-preserving Political Corruption." Pp 1-28 in Political Corruption in Africa: Extraction and Power Preservation. Cheltenham: Edward Elgar Publishing.

Anderson, Christopher J. and Yuliya V. Tverdova. 2003. "Corruption, Political Allegiances, and Attitudes toward Government in Contemporary Democracies." American Journal of Political Science 47(1): 91-109.

Ares, Macarena and Enrique Hernández. 2017. “The Corrosive Effect of Corruption on Trust in Politicians: Evidence from a Natural Experiment." Research \& Politics 4(2): 1-8.

Balán, Manuel. 2011. "Competition by Denunciation: The Political Dynamics of Corruption Scandals in Argentina and Chile." Comparative Politics 43(4): 459-478.

Bauhr, Monika and Marcia Grimes. 2014. "Indignation or Resignation: The Implications of Transparency for Societal Accountability." Governance 27(2): 291-320. 
Bazurli, Raffaele and Martín Portos. 2019. "Crook!: The Impact of Perceived Corruption on NonElectoral Forms of Political Behaviour." International Political Science Review 1-16.

Beck, Adrian and Ruth Lee. 2002. "Attitudes to Corruption amongst Russian Police Officers and Trainees." Crime, Law and Social Change 38(4): 357-372.

Birch, Sarah. 2010. "Perceptions of Electoral Fairness and Voter Turnout." Comparative Political Studies 43(12): 1601-1622.

Blackburn, Keith, Niloy Bose, and Emranul M. Haque. 2006. "The Incidence and Persistence of Corruption in Economic Development." Journal of Economic Dynamics and Control 30(12): 2447-2467.

Blackburn, Keith, Niloy Bose, and Emranul M. Haque. 2010. "Endogenous Corruption in Economic Development.” Journal of Economic Studies 37(1): 4-25.

Bonifácio, Robert and Rafael Paulino. 2015. "Corruption and Political Participation in the Americas and the Caribbean." Brazilian Political Science Review 9(2): 54-80.

Buben, Radek and Karel Kouba. 2017. "Proportional Representation, Large District Magnitude and Closed Lists." World Political Science 13(2): 151-191.

Caillier, James. 2010. "Citizen Trust, Political Corruption, and Voting Behavior: Connecting the Dots." Politics \& Policy 38(5): 1015-1035.

Camara-Fuertes, Luis Raúl and Gustavo J. Bobonis. 2015. Challenging Corrupt Politicians? Audits, Electoral Selection, and Accountability in Municipal Elections. Working paper.

Carreras, Miguel and Sofia Vera. 2018. "Do Corrupt Politicians Mobilize or Demobilize Voters? A Vignette Experiment in Colombia." Latin American Politics and Society 60(3): 77-95.

Chang, Eric C. C. and Miriam A. Golden. 2007. "Electoral Systems, District Magnitude and Corruption." British Journal of Political Science 37(1): 115-137.

Choi, Eunjung and Jongseok Woo. 2010. "Political Corruption, Economic Performance, and Electoral Outcomes: A Cross-national Analysis." Contemporary Politics 16(3): 249-262.

Chong, Alberto, Ana L. De La O, Dean Karlan, and Leonard Wantchekon. 2015. "Does Corruption Information Inspire the Fight or Quash the Hope? A Field Experiment in Mexico on Voter Turnout, Choice, and Party Identification." The Journal of Politics 77(1): 55-71.

Costas-Pérez, Elena. 2014. Political Corruption and Voter Turnout: Mobilization or Disaffection? Barcelona. Working paper.

Costas-Pérez, Elena, Albert Sofé-Ollé, and Pilar Sorribas-Navarro. 2012. "Corruption Scandals, Voter Information, and Accountability.” European Journal of Political Economy 28(4): 469-484.

Dahlberg, Stefan and Maria Solevid. 2016. "Does Corruption Suppress Voter Turnout?" Journal of Elections, Public Opinion and Parties 26(4): 489-510.

Dalton, Russell J. and Hans-Dieter Klingemann. 2007. The Oxford Handbook of Political Behavior. Oxford: Oxford University Press.

Dimoc, Michael A. and Gary C. Jacobson. 1995. "Checks and Choices: The House Bank Scandal's Impact on Voters in 1992." The Journal of Politics 57(4): 1143-1159.

Dočekalová, Pavla. 2012. "Definice a konceptualizace volebních podvodů [Definition and Conceptualization of Electoral Fraud].” Evropská volební studia 7(1): 17-29.

Ecker, Alejandro, Konstantin Glinitzer, and Thomas M. Meyer. 2016. "Corruption Performance Voting and the Electoral Context." European Political Science Review 8(3): 333-354.

Escaleras, Monica, Peter T. Calagno, and William F. Shughart. 2012. "Corruption and Voter Participation: Evidence from the US States." Public Finance Review 40(6): 789-815.

Fernández-Vázquez, Pablo, Pablo Barberá, and Gonzalo Rivero. 2016. "Rooting Out Corruption or Rooting for Corruption? The Heterogeneous Electoral Consequences of Scandals." Political Science Research and Methods 4(2): 379-397.

Ferraz, Claudio and Frederico Finan. 2008. "Exposing Corrupt Politicians: The Effects of Brazil's Publicly Released Audits on Electoral Outcomes.” The Quarterly Journal of Economics 123(2): 703-745. 
Figueiredo De, Miguel F. P., Daniel F. Hidalgo, and Yuri Kasahara. 2011. When Do Voters Punish Corrupt Politicians? Experimental Evidence from Brazil. Working paper.

Gingerich, Daniel W. 2009. "Corruption and Political Decay: Evidence from Bolivia." Quarterly Journal of Political Science 4(1): 1-34.

Giommoni, Tommaso. 2017. Exposition to Corruption and Political Participation: Evidence from Italian Municipalities. Working paper.

Haque, Emranul M. and Richard Kneller. 2005. "Corruption Clubs: Endogenous Thresholds in Corruption and Development." SSRN Electronic Journal 10(4): 345-373.

Hellman, Joel S., Geraint Jones, and Daniel Kaufmann. 2000. Seize the State, Seize the Day: State capture, Corruption, and Influence in Transition. The World Bank.

Hooghe, Marc and Sofie Marien. 2013. "A Comparative Analysis of the Relation between Political Trust and Forms of Political Participation in Europe.” European Societies 15(1): 131-152.

Hooghe, Marc and Ellen Quintelier. 2014. "Political Participation in European Countries: The Effect of Authoritarian Rule, Corruption, Lack of Good Governance and Economic Downturn." Comparative European Politics 12(2): 209-232.

Inglehart, Ronald. 1997. Modernization and Postmodernization: Cultural, Economic, and Political Change in 43 Societies. Princeton: Princeton University Press.

Jain, Arvind K. 2001. “Corruption: A Review.” Journal of Economic Surveys 15(1): 71-121.

Jiménez, Juan L. and Carmen García. 2018. "Does Local Public Corruption Generate Partisan Effects on Polls?" Crime, Law and Social Change 69(1): 3-23.

Kaase, Max. 1999. "Interpersonal Trust, Political Trust and Non-institutionalised Political Participation in Western Europe.” West European Politics 22(3): 1-21.

Karahan, Gökhan R., Morris R. Coats, and William F. Shughart. 2006. "Corrupt Political Jurisdictions and Voter Participation." Public Choice 126(1-2): 87-106.

Kostadinova, Tatiana. 2003. "Voter Turnout Dynamics in Post-Communist Europe." European Journal of Political Research 42(6): 741-759.

Kostadinova, Tatiana. 2009. "Abstain or Rebel: Corruption Perceptions and Voting in East European Elections." Politics \& Policy 37(4): 691-714.

Kostadinova, Tatiana and Zoltán Kmetty. 2019. "Corruption and Political Participation in Hungary: Testing Models of Civic Engagement.” East European Politics and Societies 33(3): 555-578.

Inman, Kris and Andrews T. Josephine. 2015. "Corruption and Voting in Senegal: Evidence from Experimental and Survey Research." African Journal of Political Science and International Relations 9(3): 100-114.

Kunieda, Takuma, Keisuke Okada, and Akihisa Shibata. 2016. "Corruption, Financial Development and Economic Growth: Theory and Evidence from an Instrumental Variable Approach With Human Genetic Diversity." Economic Notes 45(3): 353-392.

Kurer, Oskar. 2015. "Definitions of Corruption." Pp. 30-41 in Routledge Handbook of Political Corruption, edited by P. M. Heywood. Abingdon: Routledge.

Latin American Public Opinion Project. 2019. “AmericasBarometer Questionnaires.” Retrieved December 15, 2019 (https://www.vanderbilt.edu/lapop/core-surveys.php).

Latinobarómetro. 2019. "Latinobarómetro Questionnaire.” Retrieved December 15, 2019 (http://www. latinobarometro.org/latContents.jsp).

Lin, Min-Wei and Chilik Yu. 2014. "Can Corruption Be Measured? Comparing Global Versus Local Perceptions of Corruption in East and Southeast Asia." Journal of Comparative Policy Analysis: Research and Practice 16(2): 140-157.

Machado, Fabiana, Carlos Scartascini, and Mariano Tommasi. 2011. "Political Institutions and Street Protests in Latin America." Journal of Conflict Resolution 55(3): 340-365. 
Manzetti, Luigi and Carole J. Wilson. 2007. "Why Do Corrupt Governments Maintain Public Support?" Comparative Political Studies 40(8): 949-970.

Mccann, James A. and Jorge I. Domínguez 1998. "Mexicans React to Electoral Fraud and Political Corruption: An Assessment of Public Opinion and Voting Behavior." Electoral Studies 17(4): 483-503.

Morris, Stephen D. 2008. "Disaggregating Corruption: A Comparison of Participation and Perceptions in Latin America with a Focus on Mexico." Bulletin of Latin American Research 27(3): 388-409.

Muñoz, Jordi, Eva Anduiza, and Aina Gallego. 2016. "Why do Voters Forgive Corrupt Politicians? Cynicism, Noise and Implicit Exchange." Local Government Studies 42(4): 598-615.

Myerson, Roger B. 1993. "Effectiveness of Electoral Systems for Reducing Government Corruption: A Game-Theoretic Analysis." Games and Economic Behavior 5(1): 118-132.

Navot, Doron and Itai Beeri. 2017. "Conceptualization of Political Corruption, Perceptions of Corruption, and Political Participation in Democracies." Lex localis - Journal of Local Self-Government 15(2): 199-219.

Naxera, Vladimír. 2012. “Občanská společnost, korupce a (ne) důvěra-dílčí příspěvek k pochopení povahy a dopadů korupce v postkomunistických společnostech" [Civil Society, Corruption, and (Mis)trust]. Acta Fakulty filozofické Západočeské univerzity v Plzni (3): 103-120.

Neshkova, Milena I. and Vaiva Kalesnikaite. 2019. "Corruption and Citizen Participation in Local Government: Evidence from Latin America.” Governance 32(4): 677-693.

Nye, Joseph S. 1967. "Corruption and Political Development: A Cost-Benefit Analysis." American Political Science Review 61(2): 417-427.

Obydenkova, Anastassia V. and Bruno Arpino. 2018. "Corruption and Trust in the European Union and National Institutions: Changes over the Great Recession across European States." Journal of Common Market Studies 56(3): 594-611.

Olsson, Sofia A. 2014. Corruption and Political Participation. Working paper.

Pattie, Charles and Ron Johnston. 2012. "The Electoral Impact of the UK 2009 MPs' Expenses Scandal." Political Studies 60(4): 730-750.

Persson, Torsten, Guido Tabellini, and Francesco Trebbi. 2003. "Electoral Rules and Corruption.” Journal of the European Economic Association 1(4): 958-989.

Peters, John G. and Susan Welch. 1980. "The Effects of Charges of Corruption on Voting Behavior in Congressional Elections." American Political Science Review 74(3): 697-708.

Praino, Rodrigo, Daniel Stockemer, and Vincent G. Moscardelli. 2013. "The Lingering Effect of Scandals in Congressional Elections: Incumbents, Challengers, and Voters.” Social Science Quarterly 94(4): $1045-1061$.

Putnam, Robert D. 1993. Making Democracy Work: Civic Traditions in Modern Italy. Princeton: Princeton University Press.

Richey, Sean. 2010. "The Impact of Corruption on Social Trust." American Politics Research 38(4): 676-690.

Riera, Pedro, Pablo Barberá, Raúl Gómez, Juan A. Mayoral, and José R. Montero. 2013. “The Electoral Consequences of Corruption Scandals in Spain." Crime, Law and Social Change 60(5): 515-534.

Roca, Thomas. 2010. Assessing Corruption: Expert Surveys versus Household Surveys, Filling the Gap. Working paper.

Shaffer, Stephen D. 1981. "A Multivariate Explanation of Decreasing Turnout in Presidential Elections, 1960-1976.” American Journal of Political Science 25(1): 68-95.

Simpser, Alberto. 2004. Making Votes Not Count: Strategic Incentives for Electoral Corruption. Working paper.

Solé-Ollé, Albert and Pilar Sorribas-Navarro. 2018. "Trust No More? On The Lasting Effects of Corruption Scandals.” European Journal of Political Economy 55: 185-203. 
Stockemer, Daniel. 2013. "Corruption and Turnout in Presidential Elections: A Macro-Level Quantitative Analysis." Politics \& Policy 41(2): 189-212.

Stockemer, Daniel and Patricia Calca. 2013. "Corruption and Turnout in Portugal—a Municipal Level Study." Crime, Law and Social Change 60(5): 535-548.

Stockemer, Daniel, Bernadette La Montange, and Lyle Scruggs. 2013. "Bribes and Ballots: The Impact of Corruption on Voter Turnout in Democracies." International Political Science Review 34(1): 74-90.

Sun, Yan. 2001. "The Politics of Conceptualizing Corruption in Reform China." Crime, Law and Social Change 35(3): 245-270.

Sundström, Aksel and Daniel Stockemer. 2015. "Regional Variation in Voter Turnout in Europe: The Impact of Corruption Perceptions.” Electoral Studies 40: 158-169.

Školník, Milan. 2019. "Není korupce jako korupce: vnímání a zkušenost ve vztahu k politické participaci" [There's no Corruption like Corruption: Perception and Experience in Relation to Political Participation]. Acta Fakulty Filozofické Západočeské Univerzity v Plzni 11(2): 22-39.

Školník, Milan. 2020. "The Effects of Corruption on Various Forms of Political Participation in Colombia." Latin American Policy 11(1): 88-102.

The Electoral Integrity Project. 2019. "Downloadable Datasets." Retrieved December 15, 2019 (https:// www.electoralintegrityproject.com/data).

The Enterprise Survey. 2019. "Corruption Data." Retrieved December 15, 2019 (https://www. enterprisesurveys.org/en/data/exploretopics/corruption).

Transparency International. 2019. "Definition of Corruption.” Retrieved December 15, 2019 (https:// www.transparency.org/what-is-corruption).

Treisman, Daniel. 2007. "What Have We Learned About the Causes of Corruption from Ten Years of Cross-National Empirical Research?” Annual Review of Political Science 10(1): 211-244.

Truex, Rory. 2011. "Corruption, Attitudes, and Education: Survey Evidence from Nepal." World Development 39(7): 1133-1142.

Tsaturyan, Sevak and Phillip J. Bryson. 2010. "Corruption and Development: The Armenian Case." International Journal of Economic Policy in Emerging Economies 2(4): 356-371.

Tucker, Joshua A. 2007. "Enough! Electoral Fraud, Collective Action Problems, and Post-Communist Colored Revolutions.” Perspectives on Politics 5(3): 537-553.

Vivyan, Nick, Markus Wagner, and Jessica Tarlov. 2012. "Representative Misconduct, Voter Perceptions and Accountability: Evidence from the 2009 House of Commons Expenses Scandal.” Electoral Studies 31(4): 750-763.

Vries De, Catherine and Hector Solaz. 2017. "The Electoral Consequences of Corruption." Annual Review of Political Science 20: 391-408.

Warren, Mark E. 2004. "What Does Corruption Mean in a Democracy?" American Journal of Political Science 48(2): 328-343.

Warren, Mark E. 2015. "The Meaning of Corruption in Democracies." Pp. 42-56 in Routledge Handbook of Political Corruption, edited by P. M. Heywood. Abingdon: Routledge.

Weber Abramo, Claudio. 2008. "How Much Do Perceptions of Corruption Really Tell Us?" Economics: The Open-Access, Open-Assessment E-Journal 2(3): 1-56.

Welch, Susan and John R. Hibbing. 2006. "The Effects of Charges of Corruption on Voting Behavior in Congressional Elections, 1982-1990." The Journal of Politics 59(1): 226-239.

Weng, W. W., C. K. Woo, Y. S. Cheng, T. Ho, and I. Horowitz. 2015. "Public Trust and Corruption Perception: Disaster Relief." Applied Economics 47(46): 4967-4981.

Xezonakis, Georgios, Spyros Kosmidis, and Stefan Dahlberg. 2016. "Can Electors Combat Corruption? Institutional Arrangements and Citizen Behaviour.” European Journal of Political Research 55(1): $160-176$. 


\section{Author}

Milan Školnik is a Ph.D. student of the Department of Political Science, Philosophical faculty of the University of Hradec Králové. His current research focuses on corruption, public administration, and political participation.

Contact: skol.milan@gmail.com 